To Cite: Kuru A, Tok E, Agdas GM, Demir HH, Ozcan HK, Demir G. GIS and Multicriteria Decision Analysis for Landfill Site Selection in Edirne Province, Turkey. Journal of the Institute of Science and Technology, 11(2): 969-981.

\title{
GIS and Multicriteria Decision Analysis for Landfill Site Selection in Edirne Province, Turkey
}

\section{Azem KURU ${ }^{1}$, Ezgi TOK ${ }^{1}$, Merve GUROGLU AGDAS ${ }^{1}$, Hacer Handan DEMIR ${ }^{2}$, Hüseyin Kurtulus OZCAN ${ }^{3}$, Goksel DEMIR ${ }^{4}$}

\begin{abstract}
A sustainable solid waste management system planning is a complex and interdisciplinary subject, which requires considering technical, environmental, economic, and social factors. Landfills play an essential role in solid waste management strategies, and landfilling is an extensively accepted preference for the clearance of solid waste worldwide. Site selection of landfill facilities can be a considerable problem as all infrastructural projects can deteriorate the ecology of the site on which they are developed because of changing land uses, loss of habitats, and displacement of fauna. These effects are mainly specific for location and need to be evaluated on every example. Landfill site selection is related to certain factors and limitations defined by natural and artificial thresholds and/or legislation. Legal provisions may vary according to the country's policy and even to the provincial policies. In addition to these features of study zones or sites, landfill site selection methods may have different criteria and sub-criteria in identifying parameters. This paper aims to identify landfill site(s) multicriteria decision analysis depending on Edirne's environmentally sensitive areas by using the Geographic Information System (GIS) technique. Data of land use, geologic features, protected areas, natural and archeological sites, transportation network, hydrological data, soil suitability for agricultural activities, and land capability classes which have been acquired from the relevant public authorities were used to proposed model. Regional factors were identified and assessed according to the risk of contamination for environmental components such as natural resources, sensitive ecosystems, and unique habitats. The chosen criteria were graded in this context, and alternative landfill sites were proposed by applying GIS-based analysis. According to the analysis, the northern subprovince of the study area, Lalapasa, has the most appropriate landfill sites.
\end{abstract}

Keywords: Landfill, Site Selection, GIS, Multi Criteria Decision Analysis, Edirne

\footnotetext{
${ }^{1}$ Azem KURU (Orcid ID: 0000-0002-3239-1179), Ezgi TOK (Orcid ID: 0000-0002-0427-5904), Merve GUROGLU AĞDAŞ (Orcid ID: 0000-0003-4416-0842), Kırklareli University, Faculty of Architecture, Department Urban and Regional Planning, Kayali Campus, 39100, Kurklareli,Turkey

${ }^{2}$ Hacer Handan DEMIR (Orcid ID: 0000-0001-6157-9181), Istanbul Gelişim University, School of Applied Science Department of Logistics, 34310, Avcilar, Istanbul, Turkey

${ }^{3}$ Hüseyin Kurtulus OZCAN (Orcid ID: 0000-0002-9810-3985) University-Cerrahpasa, Engineering Faculty, Department of Environmental Engineering, 34320 Avcilar, Istanbul, Turkey

${ }^{4}$ Goksel DEMIR (Orcid ID: 0000-0002-7815-1197) Health Sciences University, Turkey, Department of Occupational Health and Safety Department, 34668 Uskudar, Turkey

*Sorumlu Yazar/Corresponding Author: Hüseyin Kurtuluş Özcan e-mail: hkozcan@istanbul.edu.tr
} 


\section{INTRODUCTION}

The population growth in urban areas boosts consumption per capita, which results in waste production. The natural environment and public health are under the pressure of waste production. Therefore, waste management is a vital requirement to maintain a sustainable environment and reduce the negative effects of wastes on the environment and public health (Di Vaio et al., 2019). A landfill is an engineered technic for disposing of waste in specially built and preserved bodies on the land surface or in excavations into the land surface. Within the landfill, biological, chemical, and physical processes occur, and they promote the degradation of wastes and result in the formation of leachate and gases. Landfills play an essential role in waste management strategies, and landfilling is a feasible and commonly accepted solution for the disposal of solid waste worldwide and in Turkey (Vaverková et al., 2019). Site selection of waste management facilities can be a significant issue, as all infrastructural projects can damage the site's ecology. They are developed, causing landscape changes, loss of habitats, and displacement of fauna. Such impacts are generally site-specific and need to be assessed on a caseby-case basis (Danthurebandara et al., 2012). During the process of site selection, an environmental impact assessment should be done so that the optimum solution that provides the lowest cost and promotes the lowest range in ecological impact risk assessment is accomplished (Beskese et al., 2015)

Landfill site selection is related to specific factors and limitations defined by natural and artificial thresholds and legislation. Legal provisions may vary according to the country's policy and even to the provincial policies. In addition to these features of study zones or sites, landfill site selection methods may have different criteria and sub-criteria in identifying parameters (Wang et al., 2018). Consequently, various researches have different factors and limitations depending on the characteristics of the study sites, governmental policies, and socio-economic structure. In this context, potential/non-potential lands are determined for landfill site selection according to national and international legislation and suitability criteria. In this study criteria were grouped into four categories as follows: Natural, Morphological, Environmental, Public Health and Socio-economic criteria. Suitable landfill site selection analyses require processing a large amount of spatial data, which involve complicated factors and strict regulations. However, within these criteria, these parameters may vary according to the subjective case of the study area (Ball, 2005; Sener et al.,2006; Guiqin et al.,2009; Sener et al., 2010; Donevska et al., 2012).

Multicriteria evaluation for landfill site selection is difficult and time-consuming using traditional methods. In such studies, Geographical Information Systems (GIS) serve the multicriteria analysis function to evaluate complicated and various parameters on location selection and provide different scenarios. In addition, GIS allows accurate and precise results for site selection of landfill (Sadek et al., 2006; Moeinaddini et al., 2010; Nazari et al., 2011; Gorsevski et al., 2012; Khan et al., 2019). GIS is an integrative approach to solve complex planning and management problems efficiently by using spatial querying, spatial analysis, decision analysis, model analysis, visualization, and intelligent map functions (Lunkapis et al., 2002; Vatalis and Manoloadis, 2002; Sadek et al., 2006; Akbari et al., 2008; Baskurt and Aydin 2018). Therefore, GIS are utilized in many applications, including spatial data analysis such as identification, monitoring, evaluation and optimization of landfill site selection processes (Sadek et al., 2006; Ersoy and Bulut, 2009; Nas et al., 2010; Vasilyevic et al., 2012; Alavi et al., 2013; Chicherin et al., 2018; Ali et al., 2019). Nas et al. (2010) has conducted a GIS-based site selection for municipal solid waste in Konya. Land cover map and land slope map of the study area, proximity to transportation facilities, wells, archaeological sites and urban areas are the factors used. Sener et al. (2011) select the most proper locations for a landfill in Uluborlu Basin of Isparta by using GIS environment. Lithology, 
surface water, groundwater depth, elevation, slope, aspect, land use, aquifer, and proximity to roads are the mainly used critera for the process. Arkoc (2014), performing a series of analyses for choosing municipal solid waste landfills in the study area of Corlu, the subdistrict of Tekirdag by using factors consist of geological and natural, environmental, social, and economical. GIS based overlay analysis and graduation methods used in the study. Sener et al. (2011) has choosen sites for a landfill in the study area of Beysehir Lake Catchment area with the help of multicriteria decision analysis and GIS applications. Proximity to settlemets and roads, water bodies, protected areas; geology and hydrogeology, land use, aspect, and slope are the main criteria. Celiker et al. (2019) has conducted a landfill site selection process by using GIS and multicriteria decision method in Elazig, Turkey. They consider nine different criteria: proximity to transportation network, residential areas, streams, wells; geology, aspect, slope, land use, and land capability classification. Bilgilioglu and Bilgilioglu (2017) select suitable sites for landfill for Aksaray, Turkey, by using analytical hierarchy process and GIS. They use mainly the same criteria as before explained.

This paper aims to identify landfill site(s) multicriteria decision analysis depending on environmentally sensitive areas in Edirne by using the GIS technique. Regional factors were identified and assessed according to the risk of contamination for environmental components such as natural resources, sensitive ecosystems, and unique habitats. The chosen criteria were graded in this context, and alternative landfill sites were proposed by applying GIS-based analysis.

\section{MATERIALS AND METHODS}

\section{Study Area}

The city of Edirne is located in the Thrace part of the Marmara Region in northwestern Turkey on the south coast of the Aegean Sea at an altitude of 41 meters above sea level. The province has 88 kilometers of land border with Bulgaria in the west and has 204 kilometers of land border with Greece in the southwest (Figure 1). It has a total population of 401701 with $6276 \mathrm{~km}^{2}$ surfaces. Continental climate zone covers the region (EUPDE, 2015).

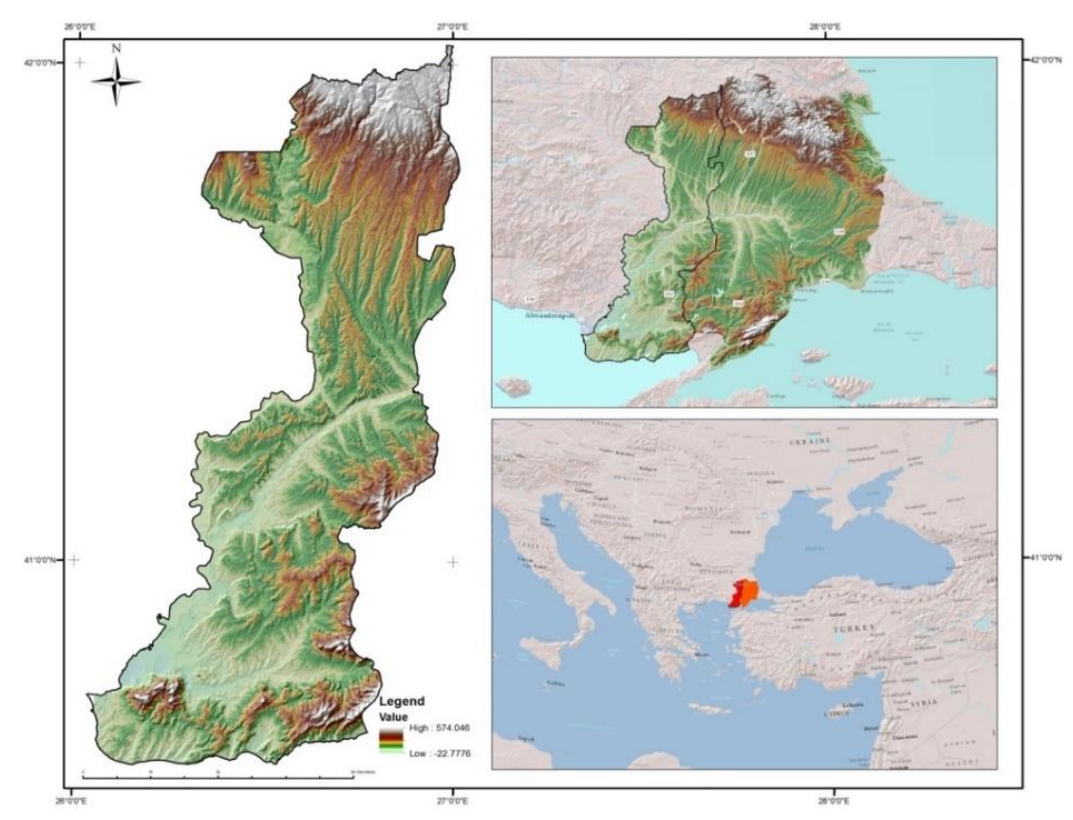

Figure 1. Location of Study Area

Eighty percent of the provincial land is suitable for agriculture in the study area and surrounds Ergene and Maritza Plains. Most of the local land is comprised of class I., II., and III. soils with respect to the land capability classification system. Therefore provincial land is considered prime agricultural 
land due to the Soil Protection and Land Use Law (Soil Protection and Land Use Law, 2005). The selected study area also has significant underground and surface water resources such as Maritza, Tunca, and Ergene rivers. Conservation statutes cover up to $38.60 \%$ of the overall protected areas in the region of Thrace. Also, the study area has $40 \%$ of Urban and Historical Conservation Areas in Thrace: Gala Lake National Park (6087 ha), Gökçetepe National Park (50 ha), Danişment National Park (13.19 ha), and Wild Life Protection Area of Mount Koru areas. In the Gala Lake National Park, 163 bird species, 16 fish species, and 300 plant species have been identified, of which 5 are endemic plant species. The Maritza delta consists of the most sensitive ecosystems in the region, which encompasses the Gala Lake National Park (EUPDE, 2015).

The population growth rate is slow in the Edirne district (Figure 2). Most of the population lives in urban areas. Population growth rate directly increases waste production, while inappropriate landfill site selection can cause various environmental problems. The unsuitable landfill site selection has a negative impact on the city's natural resources and has a socio-economic cost. There is an urgent need for landfill site selection in the city to conserve ecological balance and sustainable solid waste management. According to national statistical data, a total of 200000 tonnes of municipal solid waste was generated and collected yearly. The average amount of municipal waste per capita per day was 1.81 $\mathrm{kg}$ for the study area (TUIK, 2014).

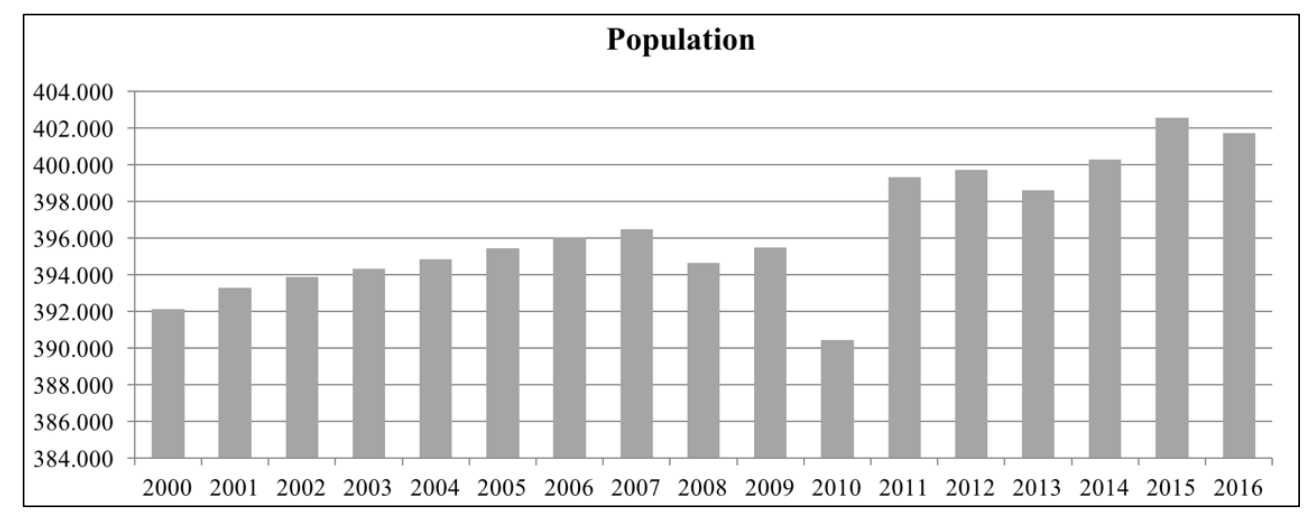

Figure 2. Yearly population of study site (TUIK, 2017)

\section{Methods}

The location selection of a new landfill area is closely related to various socio-economic and environmental aspects, such as soil science, hydrology, geology, topography, and land use. These parameters vary according to the characteristics of the study area. The first step for the study includes identifying the assessment criteria and sub-criteria in accordance with regional characteristics for use in multi-criteria decision analysis. The second step is the designation of grading values for the criteria and the sub-criteria due to the relative importance and determining the potential/non-potential areas regarding their suitability grades (Figure 3: Suitability Analysis).

In the study, the multiple-criteria ranking approach was applied for assigning scores to each identified criterion to measure the performance of the alternatives on these criteria. Environmental factors especially provide a quantitative assessment of the potential risks between a landfill area and its environment because of the siting of the landfill area.

The main criteria are selected based on the literature review explained in the introduction part of the paper and expert knowledge. Selected criteria are compiled from a comprehensive review of related literature, guidelines, researches, and legislation on landfill site selection (Figure 3. Parameter 
Definition). Parameters include slope, soil erosion, urban-industrial area, surface water, road network, forest, agricultural lands, environmentally protected areas, geology, and other aspects. Collected data are utilized in the study was shown in Table 1.

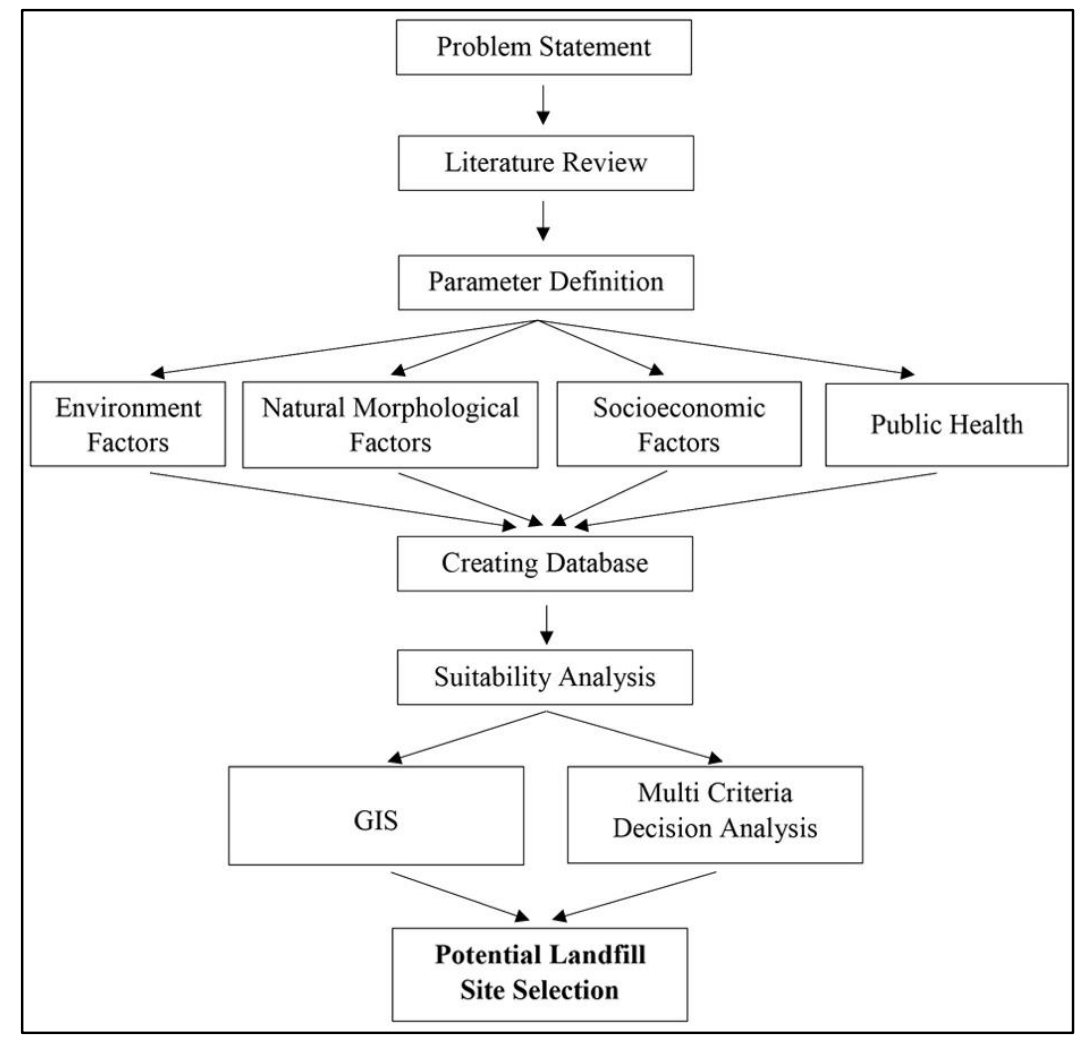

Figure 3. Flowchart of the study

Table 1. Collected Data Sources

\begin{tabular}{|c|c|c|c|}
\hline Data & Data Source/Provider & $\begin{array}{l}\text { Data } \\
\text { Type }\end{array}$ & Scale \\
\hline Land Use and Land Capability Classes & General Directorate of Rural Services & Vector & $1 / 50000$ \\
\hline Soil Suitability for Agricultural Activities & Ministry of Agriculture and Rural Affairs & Vector & $1 / 25000$ \\
\hline Geology & General Directorate of Mineral Research and Exploration & Vector & $1 / 25000$ \\
\hline Hydrology & Ministry of Agriculture and Rural Affairs & Vector & $1 / 50000$ \\
\hline Meadow Lands & Ministry of Agriculture and Rural Affairs & Vector & $1 / 50000$ \\
\hline Natural and Archeological Sides & Culture and Tourism Ministry and the Provincial Department of Culture and Tourism & Vector & $1 / 50000$ \\
\hline Protection Zone Data & Culture and Tourism Ministry and The Provincial Department of Culture And Tourism & Vector & $1 / 50000$ \\
\hline Transportation Data & General Directorate of Highways & Vector & $1 / 50000$ \\
\hline
\end{tabular}

Data of land use, geologic features, protected areas, natural and archeological sites, transportation network, hydrological data, soil suitability for agricultural activities, and land capability classes have been acquired from the relevant public authorities (Table 1). Wind direction map produced in the GIS environment by using land orientation. The data collected from relevant public authorities were designed for composing a database for the study. After data acquiring and update of the received data, the assignment of grading the criteria and sub-criteria was appraised to conduct a multi-criteria evaluation and proximity analysis to map land suitability for each criterion. Table 2 points out the parameters and their classes and grades. Graduation is made with the help of expert knowledge. When the classes take the value of 0 means unsuitable, 1 means low suitable, 3 means suitable, 5 means moderate suitable, 7 means high suitable. 


\section{GIS and Multicriteria Decision Analysis for Landfill Site Selection in Edirne Province, Turkey}

Table 2. Factors, Classes, Value and Level of Suitability

\begin{tabular}{|c|c|c|c|c|}
\hline 9,5 & Factors & Class & Value & Level of Suitability \\
\hline \multirow{20}{*}{ 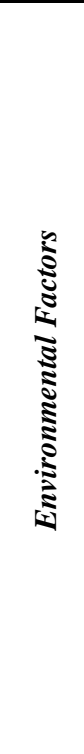 } & \multirow{5}{*}{$\begin{array}{l}\text { Distance from Domestic } \\
\text { Water Supply }\end{array}$} & $0-5000(\mathrm{~m})$ & 0 & Unsuitable \\
\hline & & $5000-6000$ & 1 & Low Suitable \\
\hline & & $6000-7000$ & 3 & Suitable \\
\hline & & $7000-10000$ & 5 & Moderate suitable \\
\hline & & $>10000$ & 7 & Highly suitable \\
\hline & \multirow{4}{*}{ Distance From Rivers } & $0-500(\mathrm{~m})$ & 0 & Unsuitable \\
\hline & & $500-1000$ & 1 & Low Suitable \\
\hline & & $1000-2000$ & 3 & Suitable \\
\hline & & $>2000$ & 5 & Moderate suitable \\
\hline & \multirow{5}{*}{$\begin{array}{c}\text { Distance From Lakes and } \\
\text { Ponds }\end{array}$} & $0-2000(\mathrm{~m})$ & 0 & Unsuitable \\
\hline & & $2000-3000$ & 1 & Low Suitable \\
\hline & & $3000-4000$ & 3 & Suitable \\
\hline & & $4000-5000$ & 5 & Moderate suitable \\
\hline & & $>5000$ & 7 & Highly suitable \\
\hline & \multirow{5}{*}{$\begin{array}{l}\text { Distance From } \\
\text { Conservation and } \\
\text { Protected Areas }\end{array}$} & $0-1000(\mathrm{~m})$ & 0 & Unsuitable \\
\hline & & $1000-3000$ & 1 & Low Suitable \\
\hline & & $3000-5000$ & 3 & Suitable \\
\hline & & $5000-7000$ & 5 & Moderate suitable \\
\hline & & $7000-10000$ & 7 & Highly suitable \\
\hline & Forest Lands & Forest lands & 0 & Unsuitable \\
\hline \multirow{8}{*}{ 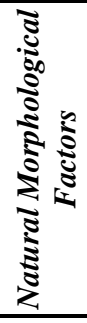 } & \multirow{4}{*}{ Slope } & $0-6(\%)$ & 7 & Highly suitable \\
\hline & & $6-12$ & 5 & Moderate suitable \\
\hline & & $12-20$ & 1 & Low suitable \\
\hline & & $>20$ & 0 & Unsuitable \\
\hline & \multirow{2}{*}{ Soil Erosion } & 1 & 7 & Highly suitable \\
\hline & & $2,3,4$ & 0 & Unsuitable \\
\hline & \multirow{2}{*}{ Geology } & Permeable & 0 & Unsuitable \\
\hline & & Impermeable & 7 & Highly Suitable \\
\hline \multirow{7}{*}{ 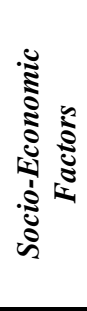 } & \multirow{5}{*}{$\begin{array}{l}\text { Accessibility (Distance } \\
\text { from Roads) }\end{array}$} & $0-100(\mathrm{~m})$ & 0 & Unsuitable \\
\hline & & $100-1000$ & 1 & Low Suitable \\
\hline & & $1000-5000$ & 5 & Moderate suitable \\
\hline & & $5000-10000$ & 7 & Highly suitable \\
\hline & & $>10000$ & 1 & Low Suitable \\
\hline & \multirow[b]{2}{*}{ Agricultural Lands } & Absolute protected areas & 0 & Unsuitable \\
\hline & & $\begin{array}{l}\text { Limited agricultural use and non- } \\
\text { agricultural permitted areas }\end{array}$ & 7 & Highly suitable \\
\hline \multirow{9}{*}{ 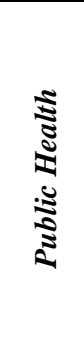 } & \multirow{5}{*}{$\begin{array}{c}\text { Distance from Urban and } \\
\text { Industrial Areas }\end{array}$} & $0-1000(\mathrm{~m})$ & 0 & Unsuitable \\
\hline & & $1000-3000$ & 1 & Low Suitable \\
\hline & & $3000-5000$ & 3 & Suitable \\
\hline & & $5000-10000$ & 5 & Moderate suitable \\
\hline & & $>10000$ & 7 & Highly suitable \\
\hline & \multirow{4}{*}{ Wind Direction } & $\mathrm{NE}-\mathrm{E}$ & 1 & Low Suitable \\
\hline & & $\mathrm{SE}-\mathrm{NW}$ & 1 & Low Suitable \\
\hline & & $\mathrm{N}-\mathrm{SW}$ & 5 & Moderate Suitable \\
\hline & & $S-W$ & 3 & Suitable \\
\hline
\end{tabular}

\section{RESULTS AND DISCUSSION}

Slope, soil erosion, and geology were analyzed to determine the potential suitability for natural morphological criteria. In this study, the slope values were categorized into four classes due to the 1:25 000 scale of the National Soil Database. The optimum percentage of slope for the landfill area was determined as $0-6 \% .516037$ ha (82\%) (Figure 4a, Table 2). The geological database of the study area was categorized according to permeability. The province has two water basins with alluvial soils, which are not convenient for landfill siting. The infiltration water generated from landfill areas can pollute groundwater. In this context, the lowest ranks were appointed to these permeable units. Also, impermeable units were scored the highest value (Figure 4b). 


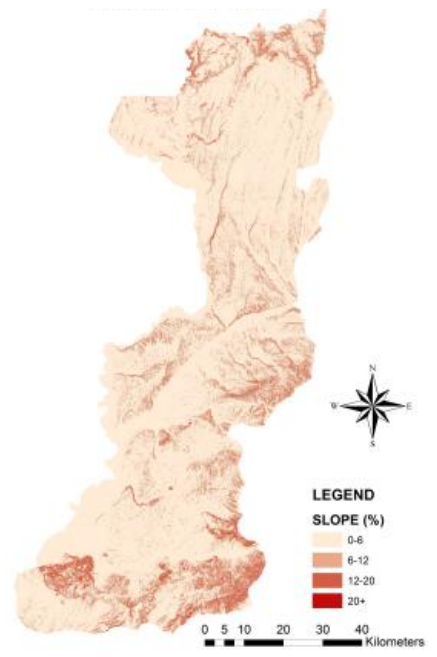

a

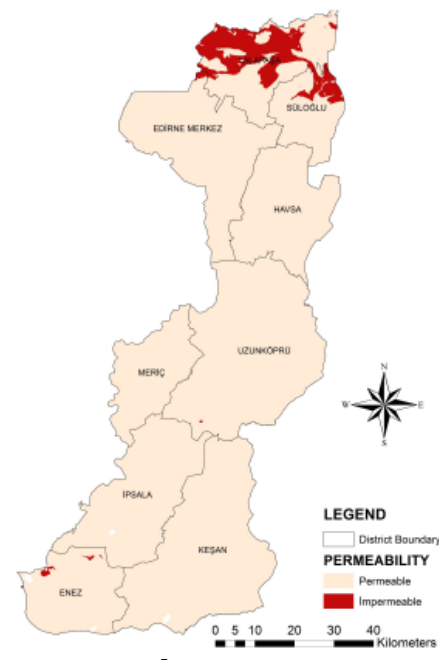

b

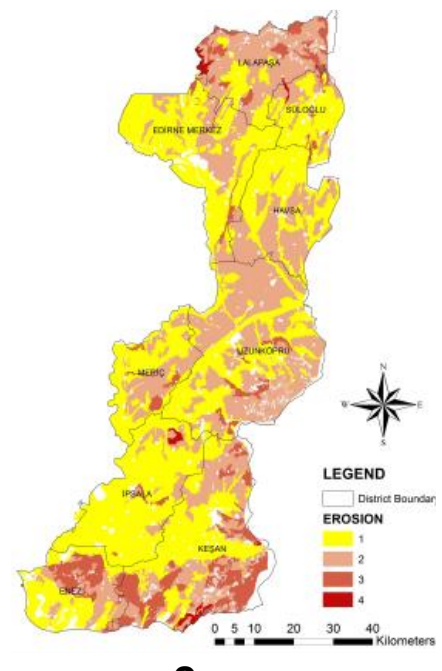

C

Figure 4. Thematic Map of Natural Morphological Factors ( a- slope, b- permeability, c-soil erosion)

There are four classes according to the intensiveness of soil erosion. Class 1 indicates none or very little erosion intensity. The rest of the categories $(2,3,4)$ were taken as one group containing lands with erosion in this process (Figure 4c). The lands with erosion haven't been included because of the Waste Management Regulation (WMR, 2015).

Landfill areas should be determined by water basin and water protection- control regulations prohibiting activities that defile the environment or natural resources. Water Pollution and Control Regulation remarks gradual precaution for domestic water and irrigation supplies. According to the foresight of regulations, the closest range protection buffer, absolute protection (0-300 m), has a strict prohibition. In this buffer zone, any public or private construction or activity has been banned. The shortrange conservation area (300-1000 m) also has strict prohibitions, but only recreational activities are allowed. In the third buffer zone, the medium-range conservation area (1000-2000 m), industrial services are not allowed. In the long-range conservation buffer zone $(2000-3000 \mathrm{~m})$, the activities that generate industrial wastewater and hazardous waste are prohibited (WPCR, 2004). In this context, the lowest value is assigned to the minimum distance to the last conservation buffer zone (Figure $5 \mathrm{a}, \mathrm{b}$ ).

The region of study has various sensitive ecosystems. One of the crucial issues for the region is natural protected areas. At the same time, archeological protected areas, urban and historical conservation areas were also assessed in this section (EUPDE, 2015). The environmental choosing of the proper waste facility site is crucial because of the specific ecological, historical, and urban characteristics of the study area. As required by the regulations, archeological, historical, and protected areas are excluded from consideration (TLPCNA, 1983). The first buffer zone is not allowed or recommended $(0-1000 \mathrm{~m})$, the minimum grade is given to the second buffer zone $(1000-3000 \mathrm{~m})$. The last buffer zone is scored as 5 (Figure 5-c). The protection of forest areas is one of the critical criteria. However, some researchers take into account the forest land as proper lands for landfill. In this study, forest lands in the province were excluded because of sensitive ecosystems (Figure 5-d). 


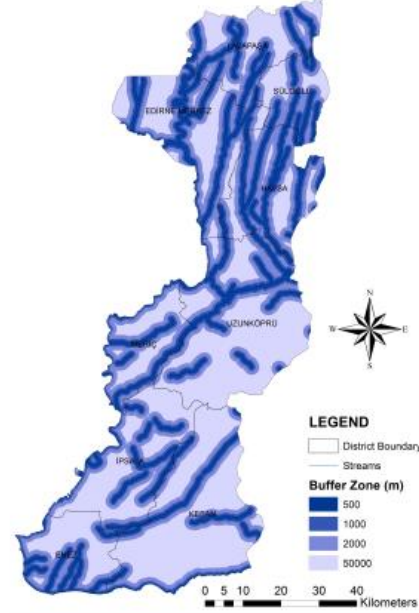

a

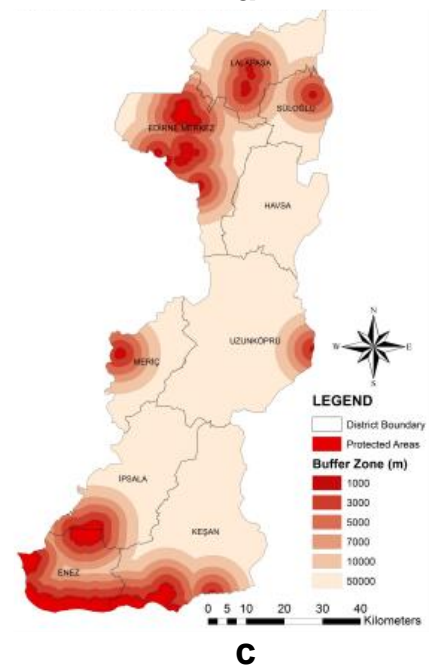

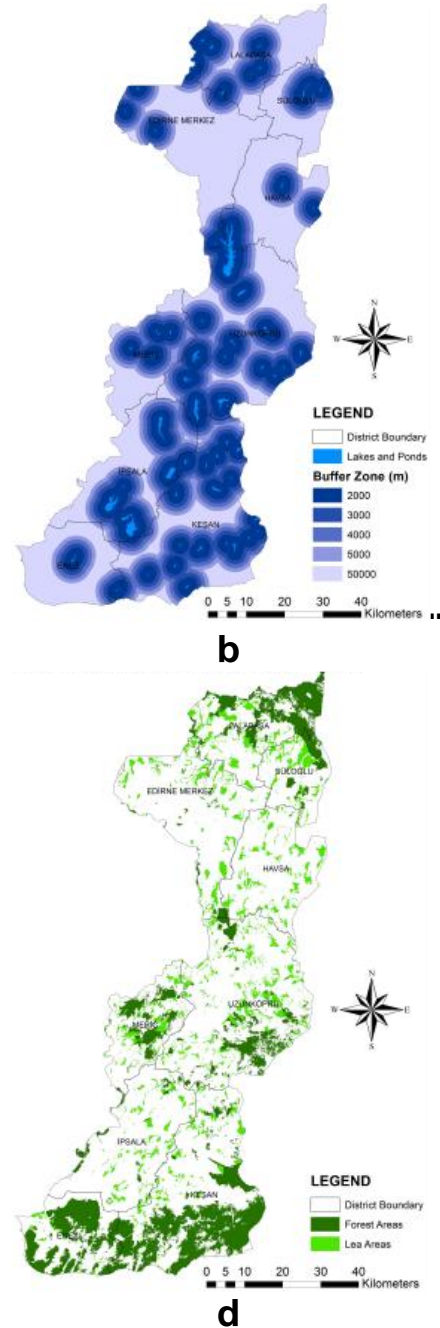

Figure 5. Thematic Map of Environmental Factors (a- streams and bufer zones, b- lakes and ponds, c-protected areas, dforest and leas)

There are certain obligations because of the potential impacts on urban and industrial areas. Also, wind directions and frequency are factors for urban areas to forbear the scent and noise. Landfill areas should be sited far from the residential areas (at least $1 \mathrm{~km}$ ) to minimize environmental impact. 1-km distance from any residential area was used according to the Waste Management Regulation. The buffer distance for urban areas within a population greater than 500 people is designated as $1000 \mathrm{~m}$ by Cantwell (Cantwell, 1999) (Figure 6a). Site morphology and wind direction are affected by the scent caused by wastes. The southeast and northwest, east and west winds are the less frequent winds; therefore, the areas affected by these wind directions were graded the highest value (Figure 6b).

Landfill should not be placed too close to roads because of health and aesthetic impacts or too far away from existing road networks to avoid high transportation costs. The index value of transportation criteria is varied in studies; $100 \mathrm{~m}$ to $1000 \mathrm{~m}$ is the most suitable distance from highways (Lunkapis et al., 2002; Leao et al., 2004; Mahini and Gholamalifard, 2006). The study area was buffered and reclassified according to its suitability by assigning a grading system from 1 to 5 . Distances of 0-100 m and $10000+m$ have the lowest grades in the study region (Figure $7 \mathrm{a}$ ).

The study area has $80 \%$ fertile land, most of which is also legally protected (EUPD, 2015). In accordance with the Soil Protection and Land Use Law, absolute agricultural lands, special product lands, planted lands, and irrigated agricultural lands cannot be used for purposes other than agricultural production purposes (SPLUL, 2005). Based on Soil Protection and Land Use Law (SPLUL), absolute 
agricultural lands, special product lands, planted lands, irrigated agricultural lands, including pasture lands, were grouped as fundamental protected agricultural areas. In this step, there are four classes, absolute protected agricultural areas, primarily protected agricultural areas, limited agricultural use areas (III land capability classes), and non-agriculture permitted areas (IV, V, VI, VII, VIII land capability classes) (Figure 7b). In the study area, there are not any military zones, airport areas, or fault lines. On account of this, these factors are not taken into consideration.
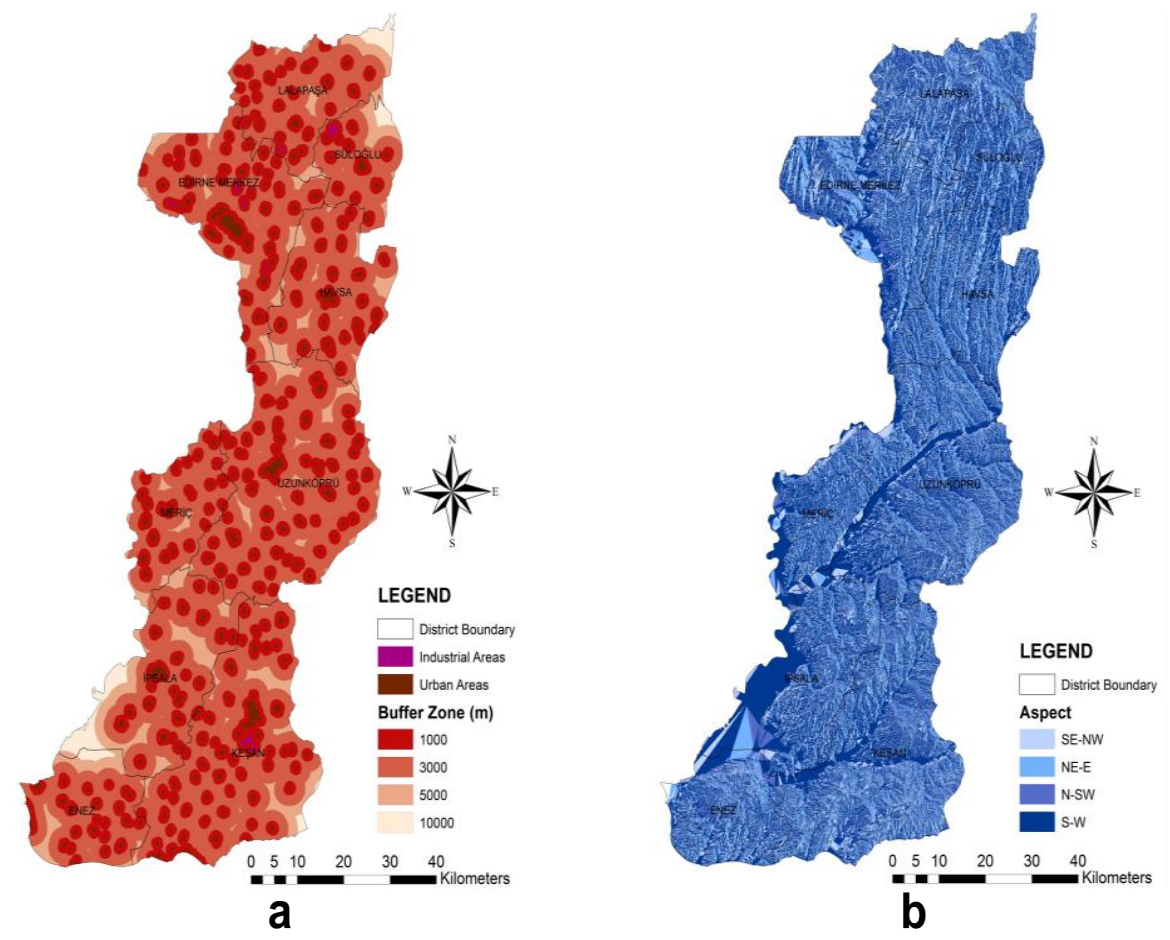

Figure 6. Thematic Map of Public Health Factors (a- urban and industry, b- wind direction)
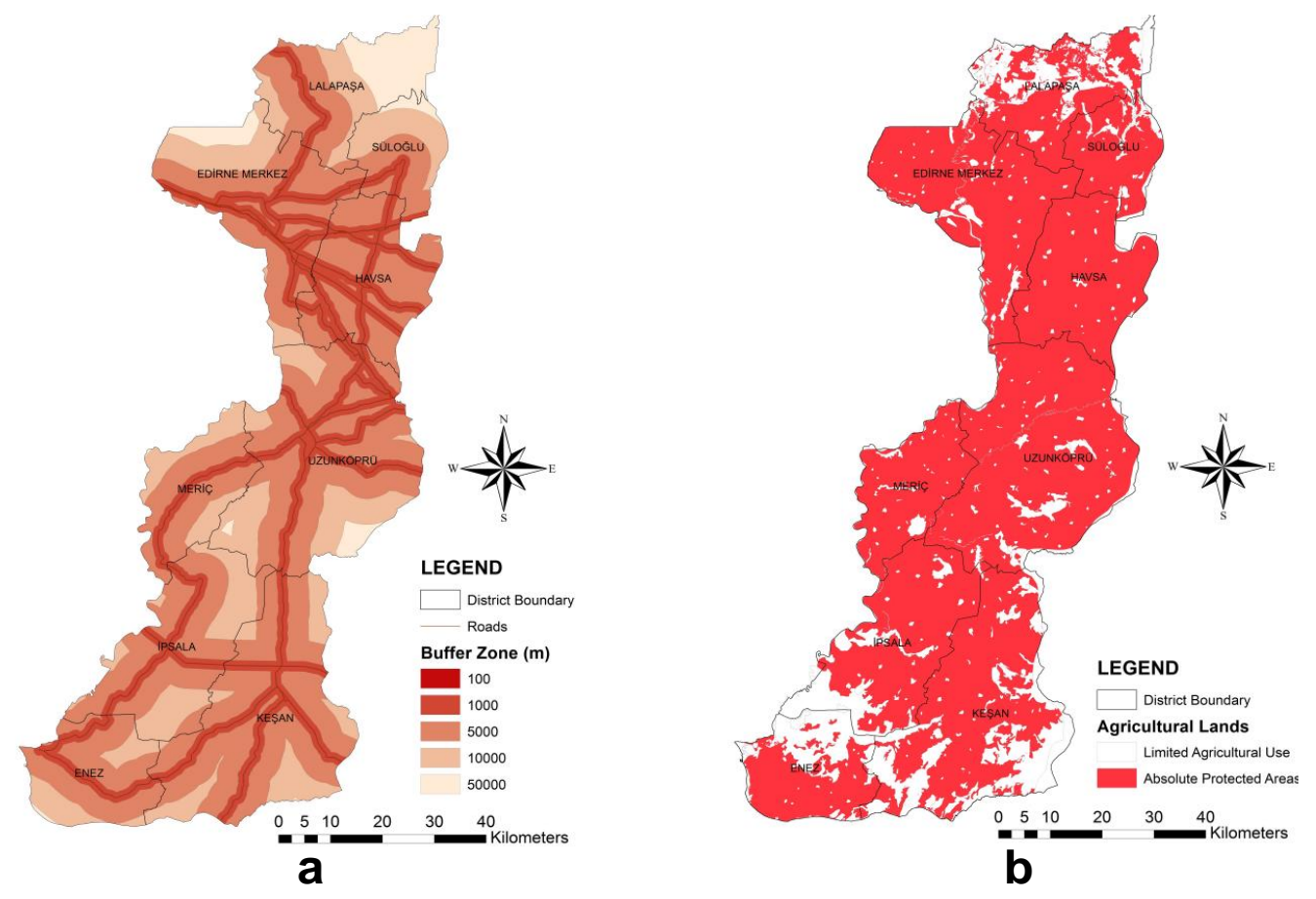

Figure 7. Thematic Map of Socio-Economic Factors (a- roads, b- agricultural areas) 
The synthesis of the grades was illustrated in the map that specifies the most suitable areas in the study area for a new landfill site (Figure 8). The total scores of all overlaid layers were determined, and the highest/lowest values were obtained. According to their grades, potential lands were grouped using Natural Breaks Methods performed on natural groupings (Jenks, 1967). There are three potential groups according to their grade range. The highest valued areas have higher potential areas. The highest value is 41 . These grades are the highest of all the other potential area scores. Generally, the minimum area size for a landfill site is approximately 5 ha. The total suitable area (18-41) is 13744 ha in the province. The first potential area (31-41) is 1991 ha. The largest undivided site is 604 ha in the second potential area (29-30).

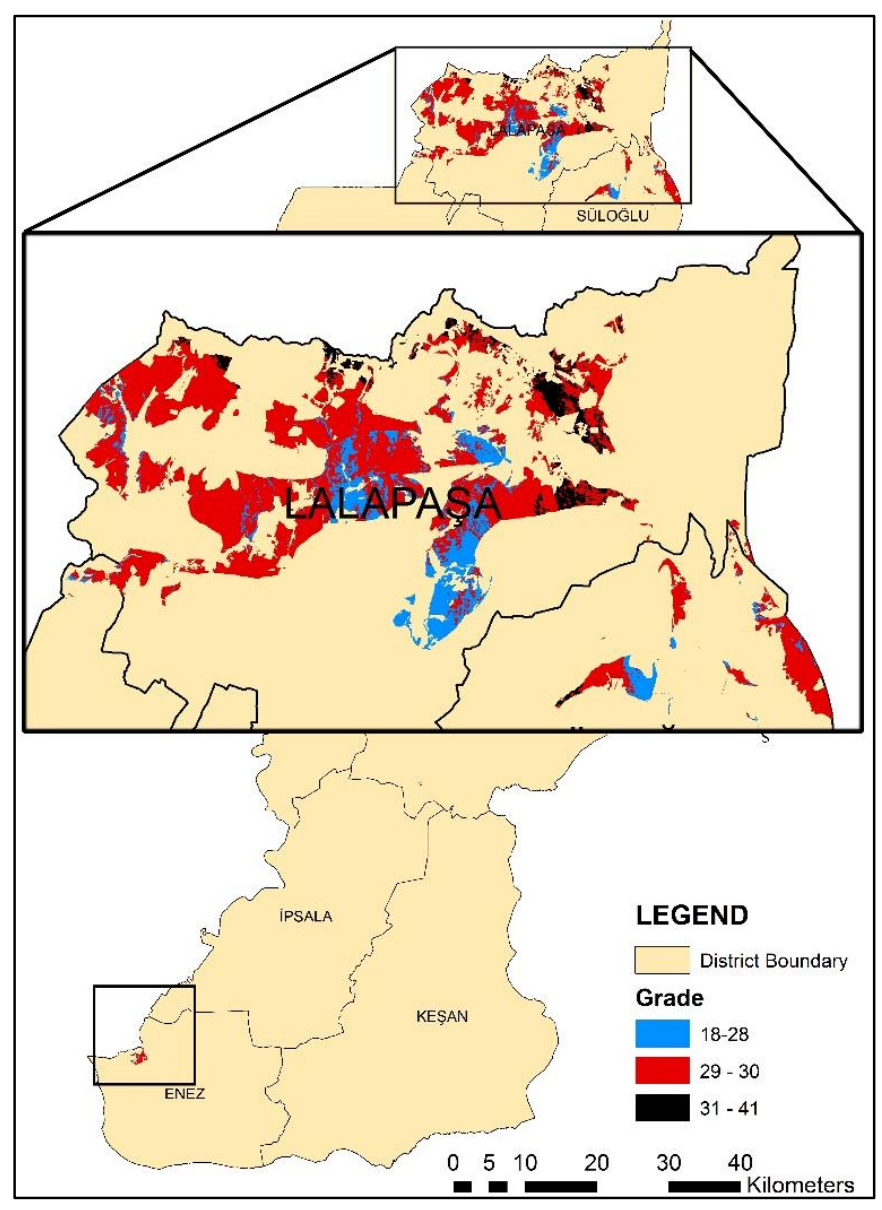

Figure 8. Suitability map for possible landfill area

\section{CONCLUSION}

This study uses spatial data analysis by Geographic Information Systems (GIS) on a new landfill site. Assessment criteria were analyzed with overlaying processes, mapped the criteria preparing in a GIS environment, and acquired appropriate regions with quantitative valuation. The final suitability map shows that potentially suitable areas are quite limited for proposed landfill sites in Edirne Province.

Edirne Province has Ergene and Maritza Water Basins, rich underground water, fertile lands, and many habitats and socio-economic values that need precaution and protection. Anthropogenic pressures are the most devastating impact on environmental retrogression. From this perspective, this study will be considered an example for other areas with similar ecological properties. 
GIS is a powerful tool to examine a spatial multicriteria decision analysis and to deliver a decision about the landfill site selection process. If the solid waste management strategies and landfill site selection processes are neglected, solid wastes become one of the most significant causes of environmental destruction. The local municipalities need technical and financial improvements on the implementation of GIS-based models. They can evolve with qualified training and the arrangement of financial resources according to these activities and data. After all these stages, it has been concluded that using multicriteria decisions in a GIS environment is a convenient tool for the landfill site selection process. Selection criteria may vary based on region and purpose. Additionally, scoring conditions may differ to provide a more ecologically friendly approach.

\section{Conflict of Interest}

The article authors declare that there is no conflict of interest between them.

\section{Author's Contilbutions}

The authors declare that they have contributed equally to the article.

\section{REFERENCES}

Akbari V, Rajabi MA., Chavoshi SH, Shams R, 2008. Landfill Site Selection by Combining GIS and Fuzzy Multi Criteria Decision Analysis, Case Study: Bandar Abbas, Iran. World Applied Sciences Journal, 3(1): 39-47.

Ali S, Taweekun J, Techato K, Waewsak J, Gyawali S, 2019. GIS Based Site Suitability Assessment For Wind and Solar Farms in Songkhla, Thailand, Renewable Energy, 132: 1360-1372.

Alavi N, Goudarzi G, Babaei AA, Jaafarzadeh N, Hosseinzadeh M, 2013. Municipal Solid Waste Landfill Site Selection with Geographic Information Systems and Analytical Hierarchy Process: A Case Study In Mahshahr County, Iran. Waste Management \& Research, 31(1): 98-105.

Arkoc, O. (2014). Municipal solid waste landfill site selection using geographical information systems: a case study from Çorlu, Turkey. Arabian Journal of Geosciences, 7(11), 4975-4985.

Ball JM, 2005. Landfill Site Selection. Tenth International Waste Management and Landfill Symposium S. Margherita di Pula, Cagliari. Italy, October 3-7, 2005, pp: 3-7.

Baskurt ZM, Aydin CC, 2018. Nuclear power plant site selection by Weighted Linear Combination in GIS environment, Edirne, Turkey, Progress in Nuclear Energy, 104: 85-101.

Beskese A, Demir HH, Ozcan HK, Okten HE, 2015. Landfill Site Selection Using Fuzzy AHP and Fuzzy TOPSIS: A Case Study for Istanbul. Environmental Earth Science, 73: 3513-3521.

Bilgilioğlu, S. S., Bilgilioğlu, B. B. (2017). Selection of suitable site for municipal solid waste disposal sites for the Aksaray (Turkey) using AHP and GIS methods. The Journal of Scientific and Engineering Research, 4(11), 36-45.

Cantwell R, 1999. Putting Data to Work-GIS and Site Selection Studies for Waste Management Facilities. Conference Proceedings, Eurogise 1999, Galway, March 26, 1999, pp:152-163.

Chicherin S, Volkova A, Latõšov E, 2018, GIS-Based Optimisation for District Heating Network Planning. Energy Procedia, 149: 635-641.

Celiker, M., Yildiz, O., Nacar Koçer, N. (2019). Evaluating solid waste landfill site selection using multi-criteria decision analysis and geographic information systems in the city of Elazı̆g, Turkey. Pamukkale University Journal of Engineering Sciences, 25(6).

Danthurebandara M, Van Passel S, Nelen D, Tielemans Y, Van Acker K, 2012. Environmental and SocioEconomic Impacts of Landfills. ECO-TECH'12, International Conference on Natural Sciences and Environmental Technologies for Waste and Wastewater Treatment Remediation Emissions Related to Climate Environmental and Economic Effects, November 26-28, 2012, Kalmar, Sweden.

Di Vaio A, Varriale L, Trujillo L, 2019. Management Control Systems in Port Waste Management: Evidence From Italy. Utilities Policy, 56: 127-135. 
Donevska KR, Gorsevski PV, Jovanovski M, Peševski I, 2012, Regional Non-Hazardous Landfill Site Selection by Integrating Fuzzy Logic, AHP and Geographic Information Systems. Environmental Earth Sciences, 67(1): 121-131.

EUPDE, Environment and Urbanisation Provincial Directorate of Edirne, 2015. Edirne İli 2015 Y1l Çevre Durum Raporu (in Turkish), S: 1-3, 57.

Ersoy H, Bulut, F, 2009. Spatial and Multi-Criteria Decision Analysis-Based Methodology for Landfill Site Selection in Growing Urban Regions. Waste Management \& Research, 27(5): 489-500.

Gorsevski PV, Donevska KR, Mitrovski CD,Frizado JP, 2012. Integrating Multi-Criteria Evaluation Techniques with Geographic Information Systems for Landfill Site Selection: A Case Study Using Ordered Weighted Average. Waste Management, 32(2): 287-296.

Guiqin W, Li Q, Guoxue L, Lijun C, 2009. Landfill Site Selection Using Spatial Information Technologies and AHP: A Case Study of Beijing, China. Journal of Environmental Management, 90: 2414-2421.

Khan MUH, Vaezi M, Kumar A, 2019. Optimal Siting of Solid Waste-To-Value-Added Facilities Through a GISBased Assessment. Science of The Total Environment, 610-611: 1065-1075.

Lunkapis JG, Ahmad N, Shariff ARM, Mansor S, Mispan RM, 2002. GIS as Decision Support Tool For Landfills Siting. 2nd World Engineering Congress, July 22-25, 2002, Sarawak, Malaysia.

Leao S, Bishop I, Evans D, 2004. Spatial-Temporal Model for Demand and Allocation of Waste Landfills in Growing in Urban Regions. Computers, Environment And Urban Systems, 28: 353-385.

Mahini SA Gholamalifard M,2006. Sitting MSW Landfills With a Weighted Linear Combination (WLC) Methodology in a GIS Environment. International Journal of Environmental Science and Technology, 3(4): 435-445.

Moeinaddini M, Khorasani N, Danehkar A, Darvishsefat AA, Zienalyan M, 2010, Siting MSW landfill Using Weighted Linear Combination and Analytical Hierarchy Process (AHP) Methodology in GIS Environment (Case Study: Karaj). Waste Management, 30: 912-920.

Nas B, Cay T, Iscan F, Berktay A 2010, Selection of MSW landfill site for Konya, Turkey using GIS and multicriteria evaluation. Environmental Monitoring and Assessment, 160(1): 491-500.

Nazari A, Salarirad MM, Bazzazi AA, 2012. Landfill Site Selection by Decision-Making Tools Based on Fuzzy Multi-Attribute Decision-Making Method. Environmental Earth Sciences, 65(6): 1631-1642.

Sadek S, El-Fadel M, Freiha F, 2006. A Multi-Criterion Modular and Flexible Decision-Aid Tool for Landfill Siting Using GIS. Twenty First International Conference on Solid Waste Technology And Management, March 26-29, 2006, USA.

Sener B, Süzen ML, Doyuran V, 2006. Landfill Site Selection by Using Geographic Information Systems. Environmental Geology, 49(3): 376-388.

Sener S, Sener E, Nas B, Karagüzel R, 2010, Combining AHP with GIS for Landfill Site Selection: A Case Study in the Lake Beyşehir Catchment Area (Konya, Turkey). Waste Management, 30(11): 2037-2046.

Şener, Ş., Şener, E., Nas, B. (2011). Landfill Site Selection by using GIS and Multicriteria Decision Analysis. Mühendislik Bilimleri ve Tasarım Dergisi, 1(3), 134-144.

Şener, Ş., Sener, E., Karagüzel, R. (2011). Solid waste disposal site selection with GIS and AHP methodology: a case study in Senirkent-Uluborlu (Isparta) Basin, Turkey. Environmental monitoring and assessment, 173(1-4), 533-554.

SPLUL, Soil Protection and Land Use Law,2005. The Official Gazette of the Turkish Republic, No: 5403.

TLPCNA, The Law of Protection of Cultural and Natural Assets, 1983. The Official Gazette of the Turkish Republic, No: 2863.

TUIK, Turkish Statistical Institute,2014 https://biruni.tuik.gov.tr/medas/?kn=119\&locale=tr, Date of Access: 02.10.2018.

Vasiljević TZ, Srdjević Z, Bajčetić R, Miloradov MV, 2012. GIS and The Analytic Hierarchy Process for Regional Landfill Site Selection in Transitional Countries: A Case Study From Serbia. Environmental Management, 49(2): 445-458. 
Vatalis K, Manoliadis O, 2002. A Two-Level Multicriteria DSS for Landfill Site Selection Using GIS: Case Study in Western Macedonia, Greece. Journal of Geographic Information and Decision Analysis, 6(1): 49-56.

Vaverková MD, Winkler J, Adamcová D, Radziemsk R, Uldrij D, Zloch J, 2019. Municipal Solid Waste Landfill - Vegetation Succession in an Area Transformed by Human Impact. Ecological Engineering, 129: 109114.

Wang Y, Li J, An D, Xi B, Tang J, Wang Y, Yang Y, 2018. Site selection for municipal solid waste landfill considering environmental health risks. Resources Conservation and Recycling, 138: 40-46.

WMR, Waste Management Regulation, 2015. The Official Gazette of the Turkish Republic, No: 29314.

WPCR, Water Pollution and Control Regulation,2004. The Official Gazette of the Turkish Republic No: 25687. 